\title{
Nueva indicación de implantes cigomáticos para la rehabilitación fija de desdentados parciales: reporte de un caso
}

\author{
A new indication for Zygomatic implants for the fixed rehabilitation \\ of the partially edentulous patient: Case report
}

M.F. Pintor Willcock' ${ }^{1}$ O. Campos Salvaterra ${ }^{2}$

Resumen: Los implantes cigomáticos están indicados en casos de reabsorciones maxilares severas. Esto permitiría eliminar la necesidad de injertos óseos o levantamientos de seno de manera de recuperar el volumen óseo necesario para rehabilitar en base a implantes convencionales, disminuyendo así la morbilidad y el tiempo de tratamiento. A continuación presentamos caso de paciente desdentado parcial superior, clase I de Kennedy, en el cual se utilizaron dos implantes cigomáticos a cada lado, emergiendo sobre el reborde, a través de una modificación de la técnica.

Palabras clave: Implantes cigomáticos; Implantes dentales; Maxilar; Cigoma; Rehabilitación oral.

Recibido: 12.09 .06

Aceptado: 01.06 .07

\begin{abstract}
Zygomatic Implants are used in the rehabilitation of severely resorbed maxillas. This eliminates the necessity of bone grafting or sinus augmentation to restore the osseous volume necessary for conventional implant rehabilitation. This also minimizes morbidity and treatment times. We present the case of a patient with a partially edentulous upper ridge, Kennedy class I, in whom two zygomatic implants were placed in each side, that emerged over the alveolar ridge crest as a result of a technique modification.
\end{abstract}

Key words: Zygomatic Implants; Dental Implants; Maxilla; Zygoma; Oral Rehabilitation.

1 Cirujano-Dentista. Becado en formación académica Clínica Alemana de Santiago. Cátedra de Cirugía Oral. Facultad de Oodntología. Universidad Mayor, Chile.

2. Cirujano-Dentista. Cirujano Máxilo-facial Servicio de Cirugía Máxilo-facial Clínica Alemana de Santiago. Servicio de Cirugía Máxilo-facial Hospital José Joaquin Aguirre. Postgrado de Implantología. Facultad de Odontología. Universidad de Chile. Chile

\section{Correspondencia:}

María Fernanda Pintor Willcock

Charles Hamilton 10038, Santiago, Chile

Email: fernandapintor@gmail.com 


\section{Introducción}

Los implantes cigomáticos creados y desarrollados por el Dr. Branemark, han sido usados como anclaje posterior para prótesis implanto-soportadas en pacientes con atrofias maxilares severas, desde $1990 .^{1-3}$ El concepto original establece la colocación de un implante único en el cigoma, bilateralmente, combinado con al menos dos implantes convencionales en el sector anterior del maxilar. ${ }^{3,4}$ Históricamente, se han descrito una serie de procedimientos para el tratamiento de maxilares atrofiados, como la elevación de seno, injertos óseos onlay, injertos óseos combinados con osteotomías Lefort l; los cuales han proporcionado un adecuado volumen óseo para la instalación de implantes. 1,2,5,6 Estas opciones de tratamiento incluyen una serie de procedimientos y la necesidad de hospitalización y obtención de hueso de sitios distantes, como la cresta ilíaca o la calota. 2,5 Estos procedimientos adjuntos han inspirado el rechazo de muchos pacientes por la gran morbilidad que conllevan. ${ }^{5}$ Una alternativa de tratamiento para este grupo de pacientes son los implantes cigomáticos, los cuales corresponden a un implante endóseo de titanio, entre 30 y $52,5 \mathrm{~mm}$ de longitud. El implante se introduce en el área del segundo premolar, atravesando el seno maxilar y fijado al cuerpo del malar. La instalación de mínimo dos implantes premaxilares en el área de los caninos o 4 en el área de caninos e incisivos centrales, permite la fabricación de prótesis híbridas. ${ }^{3-5}$

\section{Caso clínico}

Paciente de género femenino, 55 años de edad desdentada parcial superior clase I de Kennedy que presentaba remanencia de las piezas 6 a 12 en boca, consulta para rehabilitar el sector posterior. De acuerdo al estudio radiográfico presenta una gran reabsorción bilateral por neumatización del seno maxilar por lo que se planifica una reconstrucción con injerto de calota e implantes en un segundo tiempo, tratamiento que rechaza por su alta morbilidad. Por esta razón se planifica la rehabilitación en base a implantes cigomáticos, para reemplazar hasta el primer molar. Para esto se instalan dos implantes cigomáticos a cada lado, 3 de $45 \mathrm{~mm}$ y uno de $40 \mathrm{~mm}$.

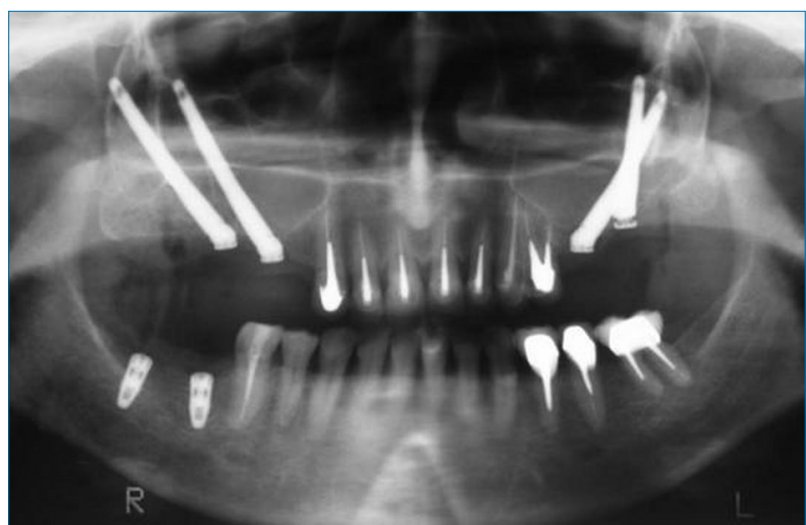

\section{Introduction}

The zygomatic implants created and developed by Dr. Branemark have been used as posterior anchors for implantsupported prostheses in patients with severe resorbed maxillae, since 1990.1-3 The original concept established the placement of a single implant in the zygoma, bilaterally, combined with at least two conventional implants in the anterior sector of the maxilla. ${ }^{3,4}$ Historically, a series of procedures have been described for treating the atrophic maxilla, such as sinus elevation, onlay bone grafts, bone grafts combined with Lefort I osteotomies; which have provided adequate bone volume for the installation of implants. 1,2,5,6 These treatment options include a series of procedures and the need for hospitalization and obtaining bone for distant sites, such as iliac crest of calvarial bone.2,5 These additional procedures have led to their rejection by many patients because of the high morbidity this entailed. ${ }^{5}$ A treatment alternative for this group of patients are zygomatic implants, which are titanium endosseous implants, between 30 and $52.5 \mathrm{~mm}$ in length. The implant is introduced in the area of the second premolar, it crosses the maxillary sinus and is fixed to the body of the malar. By fixing a minimum of two premaxillary implants in the area of the canines, or 4 in the central incisor area, hybrid prostheses can be made. . $^{3-5}$

\section{Clinical case}

Edentulous female patient, 55 years old, with a partial upper class I Kennedy with the remains of teeth 6 to 12 in her mouth. She requested at her consultation the rehabilitation of the posterior region. In accordance with the radiographic study, she had considerable bilateral resorption because of pneumatization of the maxillary sinus. As a result of this, reconstruction with a calvarial graft and implants in 
Para rehabilitar en base a prótesis fija se requería la emergencia de los implantes sobre el reborde alveolar, para lo cual se modificó la técnica original. Los implantes del lado derecho se instalaron a nivel de las piezas dentarias 3 y 4. El implante posterior se ubicó por fuera del seno maxilar y el anterior por dentro pero con una angulación mayor con respecto al plano oclusal. En el lado izquierdo, en posición de las piezas dentarias 13 y 14, el implante anterior se posicionó por fuera del seno maxilar y el implante posterior por dentro con mayor angulación (Figs. 1 y 2). Con esto se logró que los cuatro implantes emergieran en el reborde alveolar (Fig. 3) con una angulación dentro de límites aceptables (Fig. 4).

\section{Discusión}

El uso de implantes cigomáticos, evita la necesidad de utilizar injerto óseo y acorta el tiempo de tratamiento. ${ }^{2}$ El protocolo original describe la colocación de un implante cigomático a cada lado, siempre dentro de una planificación de rehabilitación en desdentados totales, principalmente debido a la desventaja que según la técnica original la plataforma del implante se ubica en palatino. 1,4,7 Esto genera problemas biomecánicos que permiten una rehabilitación solo en base a prótesis fija híbrida, genera problemas de higiene y en algunos casos problemas de articulación de la palabra. Para esto se han descrito múltiples modificaciones de esta técnica. 3,6,7 En este caso presentamos dos posibilidades que permitirían ubicar el implante cigomático en una posición cuya emergencia sea a nivel del reborde alveolar, permitiendo así, una rehabilitación en base a prótesis fija convencional en un paciente desdentado parcial como en este caso. La primera opción consiste en introducir el implante cigomático por fuera del seno maxilar y como otra opción se puede introducir el implante con mayor angulación, instalándose en una posición más vertical, de manera que su emergencia sea a través del rebor-

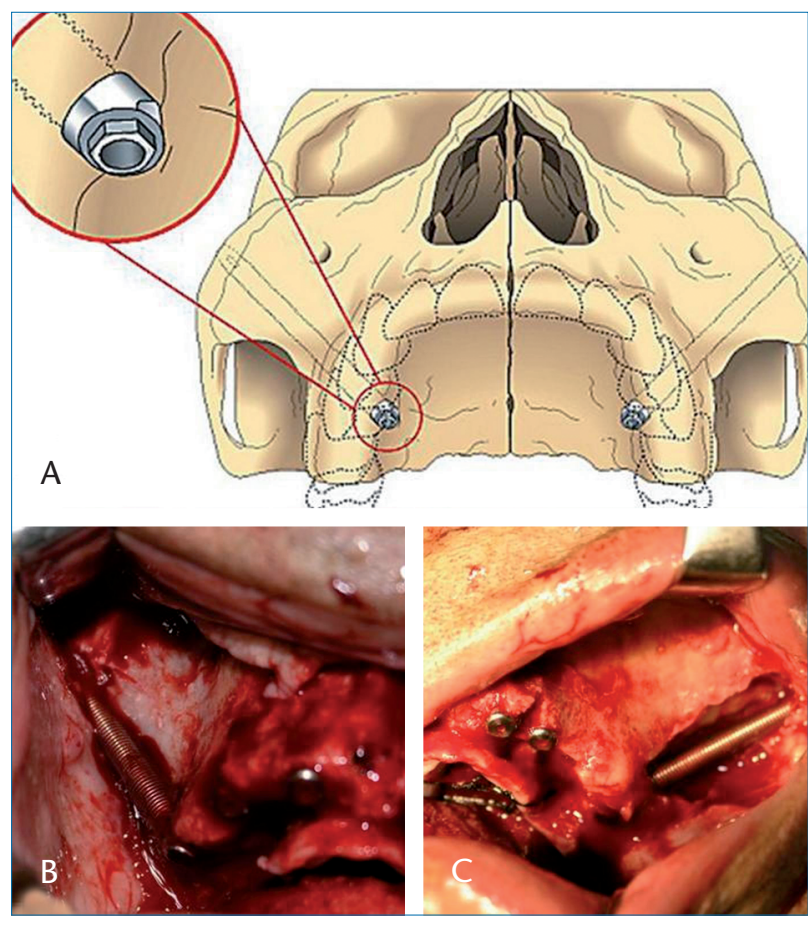

Figura 2. A) Esquema original de la relación de los implantes con el hueso maxilar y su emergencia por palatino. B y C) Implantes derechos e izquierdos emergiendo sobre el reborde. Ambos por fuera del seno maxilar.

Figure 2. A) Original diagram showing the relationship of the implants with the maxillary bone and how they emerge through the palate. $B$ and C) Right and left implants emerging over the ridge, both on the outside of the maxillary sinus.
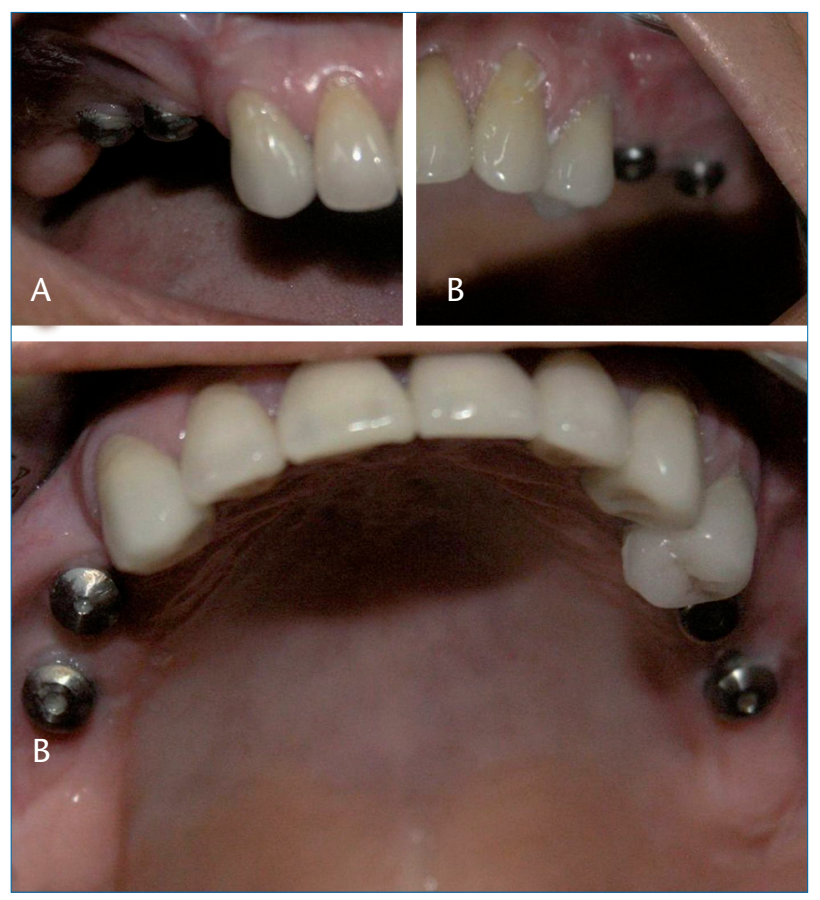

Figura 3. Imágenes Intraorales de la emergencia de los implantes con sus tornillos de cicatrización. A) Vista lateral derecha. B) Vista lateral izquierda. C) Vista oclusal.

Figure 3. Intraoral view of implants emerging with healing screws. A) Lateral view of right side. B) Lateral view of left side C) Occlusal view. a second surgical stage was planned. This treatment was rejected because of high morbidity. For this reason, rehabilitation was planned based on zygomatic implants, to replace the area up to the first molar. For this, two zygomatic implants were placed at each side, three that measured 45 $\mathrm{mm}$ and one of $40 \mathrm{~mm}$.

For a fixed prosthesis type rehabilitation the implants needed to emerge from the alveolar crest, and because of this the original technique was modified. The implants on the right side were placed by teeth 3 and 4. The posterior implant was situated outside the maxillary sinus and the anterior implant on the inside, but at a greater angle with regard to the occlusal plane. On the left side, by teeth 13 and 14, the anterior implant was positioned outside the maxillary sinus and the posterior implant on the inside at a greater angle (Figs. 1 and 2). With this the four implants were able the emerge from the alveolar ridge (Fig. 3) at an angle that was within acceptable limits (Fig. 4).

\section{Discussion}

The use of zygomatic implants avoids the need for using bone grafts and treatment times are shorterned. ${ }^{2}$ The original protocol describes placing a zygomatic implant on each side, always within a rehabilitation plan for totally edentulous patients, principally due to the disadvantage that according to the original technique, of situating the implant platform in the palate. 1,4,7 This generates biomechanical problems that permit rehabilitation based only on hybrid fixed prosthe- 
de (Fig. 5), teniendo siempre en cuenta la relación del extremo del implante con la órbita.

Si bien, el instrumental necesario para la instalación de implantes cigomáticos está diseñado para casos de pacientes desdentados totales, donde el espacio para su instalación es mayor y con una angulación determinada, se dificulta el desarrollo de la técnica en pacientes desdentados parciales con remanencia de grupos dentarios anteriores. Esto se relaciona principalmente con la longitud de las fresas. Sin embargo, creemos que ésta modificación de la técnica es posible de desarrollar sin mayores complicaciones, ampliando el espectro de indicaciones para implantes cigomáticos, con muy buenos resultados.

\section{Bibliografía}

1. Nakai H, Okazaki Y, Ueda M. Clinical application of zygomatic implants for rehabilitation of the severely resorbed maxilla: A Clinical Report. Int J Oral Maxillofac Implants 2003;18: 566-70.

2. Nkenke $\mathrm{E}$, Hahn $\mathrm{M}$, Lell $\mathrm{M}$, y cols. Anatomic site evaluation of the zygomatic bone for dental implant placement. Clin Oral Impl Res 2003; 14:72-9.

3. Bothur S, Jonsson G, Sandahl L. Modified technique using multiple zygomatic implants in reconstruction of the atrophic maxilla: $\mathrm{A}$ Technical Note. Int J Oral Maxillofac Implants 2003;18:902-4.

4. Uchida Y, Goto M, Katsuki T, Akiyoshi T. Measurement of the maxilla and zygoma as an aid in installing zygomatic implants. J Oral Maxillofac Surg 2001;59:1193-8.

5. Bedrossian E, Stumpel L, Beckely M, Indersano $T$. The zygomatic implant: preliminary data ontreatment of severely resorbed maxillae. A clinical report. Int J Oral Maxillofac Implants 2002;17:861-5.

6. Boyes-Varley JG, Howes DG, Lownie JF, Blackbeard GA. Surgical Modifications to the Brånemark Zygomaticus Protocol in the Treatment of the Severely Resorbed Maxilla: A Clinical Report. Int J Oral Maxillofac Implants 2003;18:232-7.

7. Stella JP, Warner MR. Sinus slot technique for simplification and improved orientation of zygomaticus dental implants: a technical note. Int J Oral Maxillofac Implants 2000;15:889-93.

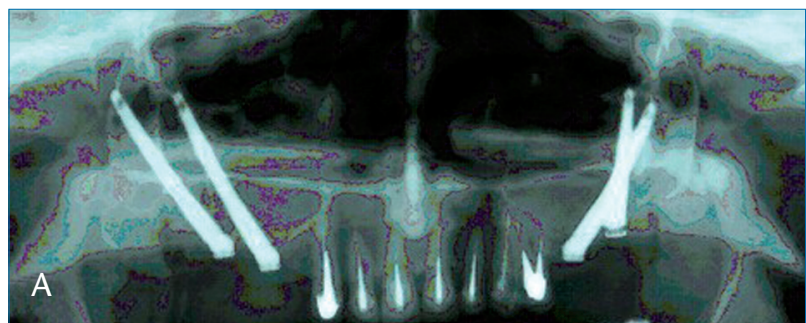

ses, leading to hygiene problems and in some cases articulation problems. Many modifications of this technique have been described. $3,6,7$ In this case we present two possibilities that permit placing the zygomatic implant in a position where it emerges from the alveolar ridge. This permits rehabilitation based on conventional fixed prostheses in partially edentulous patients, as in this case of ours. The first option consists in introducing the implant outside the maxillary sinus and another option would be to introduce it at a greater angle, placing it in a more vertical position, in such a way that it emerges through the ridge (Fig. 5), always taking into account the relationship between the end of the implant and the orbit.

While the instruments necessary for placing zygomatic implants are designed for totally edentulous patients, with a greater installation space and at a particular angle, developing the technique in partially edentulous patients with the remains of anterior dental groups, is made more difficult. This is mainly to do with the length of the drills. However, we believe that this technique modification can be developed without any major complications, thus widening the spectrum for the indications of Zygomatic Implants, with very good results. 